\title{
24-EPIBRASSINOLIDE APPLICATION ENHANCES GROWTH AND BIOCHEMICAL ASPECTS OF SQUASH UNDER SALT STRESS CONDITIONS
}

\author{
Abdelnasser Galal* \\ Department of Botany and Microbiology, Faculty of Science, Sohag University, 82524 Sohag, Egypt
}

(Received: October 3, 2017; accepted: March 6, 2018)

\begin{abstract}
Brassinosteroids (BRs) are considered to possess protective activity in plants exposed to various stresses. The present study was conducted to evaluate the effects of 24-epibrassinolide (EBL) on salt stressed summer squash cv. Eskandrani seedlings, whether it can alleviate the deleterious effects of salt stress in growing seedlings or not. For this, summer squash seeds were germinated in solidified half strength MS (Murashige and Skoog) medium supplemented with different concentrations and combinations of EBL $(0,5,10$ and $20 \mu \mathrm{M})$ and $\mathrm{NaCl}(0,50,100$ and $150 \mathrm{mM})$. The different concentrations $(5,10,20 \mu \mathrm{M})$ of EBL significantly increased germination percentage and seedling growth capacity and the greatest increase was observed at $10 \mu \mathrm{M}$ EBL. EBL application significantly increased the contents of photosynthetic pigments, the relative water content and the uptake of $\mathrm{K}$ and $\mathrm{Ca}$. However, the different concentrations $(50,100$ and $150 \mathrm{mM})$ of $\mathrm{NaCl}$ significantly decreased the above-mentioned attributes. The different concentrations $(50,100$ and $150 \mathrm{mM})$ of $\mathrm{NaCl}$ significantly increased the electrolyte leakage, the lipid peroxidation and the $\mathrm{Na}$ uptake, but the interaction between $\mathrm{EBL}$ and $\mathrm{NaCl}$ significantly decreased these parameters. The results of this study proved that the application of 24-epibrassinolide to growing squash seedlings under salt stress conditions reduced the deleterious effects of salt stress and increased the tolerance of seedlings to its detrimental effects.
\end{abstract}

Keywords: Squash - 24-epibrassinolide - electrolyte leakage - lipid peroxidation - salt stress

\section{INTRODUCTION}

Brassinosteroids (BRs) are a group of steroidal phytohormones that have high bioactivity and are widespread in the plant kingdom [48]. BRs are present in nearly every part of the plant, with the highest concentrations in the reproductive organs [13, 38]. BRs cause morphological and physiological responses in plants and improve plant growth and yield $[34,40]$. BRs have been reported to protect plants from various abiotic/biotic stresses such as drought stress [11], temperature stress [36], pathogen infection [35], heavy metals [16] and salt stress [18]. Considerable attention has been given to BRs for their positive effects during stress tolerance in a wide variety of plants such as Chlorella vulgaris [9], Cucumis sativus [47] and Pisum sativum [40].

\footnotetext{
*E-mail address: nasergalal@gmail.com
} 
Exogenous application of BRs enhanced the growth and yield of many plants by modulating protein content, antioxidant enzyme activities, seed germination, seedling growth, proline content, lipid peroxidation, photosynthetic capacity, and water relations $[12,21,40,47]$.

Soil salinity is one of the most serious agricultural problems worldwide [25]. Approximately $20 \%$ of cultivated land and $50 \%$ of cropland in the world are now under the threat from salt stress [24] and freshwater availability is now limited in some regions due to the increased urbanization $[8,23]$. In general, an excess of soluble salts resulting from natural processes or intense human practices causes ion imbalance and hyper osmotic stress which severely depress various physiological and biochemical processes in plants [24, 32], leading to a decline in growth and yield of these plants $[17,25]$. In response to high $\mathrm{NaCl}$ concentration, plants accumulate toxic ions such as $\mathrm{Na}^{+}$and $\mathrm{Cl}^{-}$[1], leading to an imbalance in mineral elements, increased membrane permeability [2], reduced photosynthetic activity and stomatal conductance $[25,30]$ and inhibited chlorophyll biosynthesis [17], however, it increases the level of proline [26] that acts as an osmoprotectant, membrane stabilizer and reactive oxygen species (ROS) scavenger [14, 39]. The effects of brassinosteroids on squash grown under salt stress have not been reported. So, the present study aimed to investigate the effects of 24-epibrassinolide on growth and biochemical aspects of summer squash cv. Eskandrani under salt stress conditions, to see whether this steroidal hormone is able to alleviate the deleterious effects of salt stress in growing seedlings of this plant or not.

\section{MATERIALS AND METHODS}

\section{Plant materials and experimental conditions}

Healthy and uniform seeds of Cucurbita pepo cv. Eskandrani were surface sterilized in $5.25 \% \mathrm{NaOCl}$ solution $(80 \% \mathrm{v} / \mathrm{v}$ commercial Clorox bleach) for $20 \mathrm{~min}$ followed by $5 \mathrm{~min}$ dip in $0.2 \%(\mathrm{w} / \mathrm{v})$ mercuric chloride $\left(\mathrm{HgCl}_{2}\right)$ and rinsed three times with sterile distilled water to remove all traces of the disinfection. Subsequently, were placed in sterile glass jars $(250 \mathrm{ml})$ containing half-strength MS [33] basal medium supplemented with $2 \%$ sucrose, $0.4 \%$ agar, and different concentrations of $\mathrm{NaCl}(0$, 50,100 and $150 \mathrm{mM}$ ). The $\mathrm{pH}$ value of the nutrient media was adjusted at $5.8 \pm 0.2$ with adding few drops of $0.1 \mathrm{~N}$ either $\mathrm{HCl}$ or $\mathrm{NaOH}$ prior to solidification and autoclaving. MS media with $\mathrm{NaCl}$ treatments were autoclaved and cooled to around $55^{\circ} \mathrm{C}$ before the addition of filter-sterilized different concentrations $(0,5,10$ and $20 \mu \mathrm{M})$ of EBL. Germination was conducted in a growth chamber under controlled environmental conditions of temperature $\left(25 \pm 2{ }^{\circ} \mathrm{C}\right)$, photoperiod regime $(16 \mathrm{~h} /$ day $)$, irradiance intensity $\left(50 \mu \mathrm{E} \mathrm{m}^{-2} \mathrm{~S}^{-1}\right)$ and humidity $(70 \%)$. Germinated seeds were counted on the third, fifth and seventh day of the experiment and the percentage of germinated seeds was calculated by the following formula: (number of germinated seeds/total number of seeds $) \times 100$. The experiment was conducted with three replicates and each repli- 
cate consisted of 4 seeds (four seeds per jar). Seedlings grown in $\mathrm{EBL}$ and $\mathrm{NaCl}$ free media were considered as control. Thirty days after sowing (DAS), plants were harvested and washed thoroughly under running tap water followed by washing with double distilled water for about 3-5 times to remove adhered nutrient agar from the roots. Finally, three plants were chosen randomly from each treatment for determination the following analyses.

\section{Growth}

Lengths of shoot and root were measured manually with a scale. Plants were divided into shoot and root and their fresh weights were recorded, then these were oven dried at $70{ }^{\circ} \mathrm{C}$ for $72 \mathrm{~h}$. Finally the dry weights of shoot and root were determined by weighing these separately using an analytical balance.

\section{Biochemical analyses}

\section{Estimation of photosynthetic pigments}

Chlorophyll and carotenoid contents were extracted from the leaves and estimated spectrophotometrically (Spekol 11, Carl Zeiss, Jena, Germany) according to Arnon [5].

\section{Proline content}

The proline content was determined using the method described by Bates et al. [10]. Proline was extracted from leaf samples of $100 \mathrm{mg} \mathrm{FW}$ with $2 \mathrm{~mL}$ of $40 \%$ methanol. One $\mathrm{mL}$ of the extract was mixed with $1 \mathrm{~mL}$ of a mixture of glacial acetic acid and orthophosphoric acid $(6 \mathrm{M})(3: 2, \mathrm{v} / \mathrm{v})$ and $25 \mathrm{mg}$ of ninhydrin. After $1 \mathrm{~h}$ incubation at $100{ }^{\circ} \mathrm{C}$, the reaction was terminated by putting the tubes in ice bath, $5 \mathrm{~mL}$ toluene was added. The absorbance of the upper phase was spectrophotometrically determined at $520 \mathrm{~nm}$. The proline concentration was determined using a standard curve.

\section{Reduced sugar content}

Reduced sugar content was measured in fresh leaves according to Dubios et al. [15]. A sample of the leaves was grounded in a mortar and pestle, and the tissue was extracted in distilled water at $78^{\circ} \mathrm{C}$. The homogenized samples were centrifuged for $10 \mathrm{~min}$ at $1000 \times \mathrm{g}$. A supernatant was used to estimate the sugar content. After keeping for $10 \mathrm{~min}$ for color development with copper sulphate and phosphomolibdic acid, solution absorbance was read at $600 \mathrm{~nm}$. The absorption was recorded using a spectrophotometer (Model UV-120-20. Japan). 


\section{Leaf relative water content}

Leaf relative water content (LRWC) was calculated based on the methods of Yamasaki and Dillenburg [45]. Leaves were first removed from the stem and then weighed to obtain fresh weight (FW). In order to determine the turgid weight (TW), leaves were floated in distilled water inside a closed Petri dish for 6 hours. The leaf samples were weighed after gently wiping the water from the leaf surface with tissue paper, then the leaf samples were placed in an oven at $80^{\circ} \mathrm{C}$ for $48 \mathrm{~h}$, in order to obtain dry weight (DW). All weight measurements were made using an analytical scale, with a precision of $0.0001 \mathrm{~g}$. Values of FW, TW and DW were used to calculate LRWC using the following equation: $\mathrm{LRWC}(\%)=[(\mathrm{FW}-\mathrm{DW}) /(\mathrm{TW}-\mathrm{DW})] \times 100$.

\section{Electrolyte leakage}

Electrolyte leakage was measured using an electrical conductivity meter as described by Lutts et al. [29]. Leaves were excised and washed with deionized water. After drying with filter paper, $1 \mathrm{~g}$ fresh weight of leaves were cut into small pieces (about $1 \mathrm{~cm}^{2}$ ) and then immersed in $20 \mathrm{~mL}$ deionized water and incubated at $25^{\circ} \mathrm{C}$. After $24 \mathrm{~h}$, electrical conductivity $\left(\mathrm{EC}_{1}\right)$ of the bathing solution was recorded. These samples were then autoclaved at $120^{\circ} \mathrm{C}$ for $20 \mathrm{~min}$ to completely kill the tissues and release all electrolytes. Samples were then cooled to $25^{\circ} \mathrm{C}$, finally electrical conductivity $\left(\mathrm{EC}_{2}\right)$ was measured. The electrolyte leakage (EL) was expressed by the following formula: $\mathrm{EL}=\mathrm{EC}_{1} / \mathrm{EC}_{2} \times 100$.

\section{Lipid peroxidation}

Lipid peroxidation was determined by measuring the amount of malondialdehyde (MDA) formed using the thiobarbituric acid reactive substances (TBARS) method described by Heath and Packer [19]. Frozen leaf samples $(0.5 \mathrm{~g})$ were homogenized in $10 \mathrm{~mL}$ of $0.1 \%$ trichloroacetic acid (TCA) and the homogenate was centrifuged at $15,000 \mathrm{rpm}$ for $15 \mathrm{~min}$. To a $1.0 \mathrm{~mL}$ aliquot of the supernatant, $4.0 \mathrm{~mL}$ of $0.5 \%$ thiobarbituric acid (TBA) in $20 \%$ TCA was added. The mixture was then heated at $95{ }^{\circ} \mathrm{C}$ for $30 \mathrm{~min}$ in an oven, and then cooled in an ice bath. After centrifugation at $\times 10,000 \mathrm{~g}$ for $10 \mathrm{~min}$, the absorbance of the supernatant was recorded at 532 and 600 $\mathrm{nm}$. The MDA content (mmol/g FW) was calculated using an extinction coefficient of $155 \mathrm{mmol} / \mathrm{cm}$ after subtracting the non-specific absorbance at $600 \mathrm{~nm}$.

\section{Determination of $\mathrm{Na}^{+}, \mathrm{K}^{+}$and $\mathrm{Ca}^{2+}$ contents}

The dried leaves were grounded to powder using a mortar and pestle. Ground samples ( $0.5 \mathrm{~g}$ per replicate) were taken up in $10 \mathrm{ml}$ nitric acid. After $24 \mathrm{~h}$ this solution was 
boiled to remove any acidic gases, then filtered into a $50 \mathrm{ml}$ volumetric flask and filled up to $50 \mathrm{ml}$ with distilled water. Potassium, sodium and calcium were determined in these sample solutions using a flame photometer (Jenway PFP7, UK).

\section{Data analysis}

Analysis of variance was performed using SAS version 9.1 (SAS Institute Inc., Cary, NC, USA). Data were presented as means \pm SD for each treatment. Means were compared according to Duncan's multiple-range test at $\mathrm{P} \leq 0.05$.

\section{RESULTS}

The different concentrations $(5,10$ and $20 \mu \mathrm{M})$ of EBL increased the germinated seed percentages. Ten $\mu \mathrm{M}$ EBL induced the highly efficacious effect than its other concentrations ( 5 and $25 \mu \mathrm{M}$ ) in terms of high germination percentage compared to control (Table 1). On the other hand, $\mathrm{NaCl}$ treatments $(50,100$ and $150 \mathrm{mM})$ significantly decreased the seed germinated percentages (73.6, 62.7 and 51.3, respectively), and the salinity levels of 100 and $150 \mathrm{mM} \mathrm{NaCl}$ induced the most drastic effects in terms of germination inhibition. This deleterious effect of salt stress on seed germination was surmounted by $10 \mu \mathrm{M}$ EBL. The similar result was observed with the growth of seedlings, the different concentrations $(5,10$ and $20 \mu \mathrm{M})$ of EBL significantly increased the growth parameters (lengths of shoot and root and dry weights of shoot and root) of seedlings (Table 1). The greatest increase in these parameters was

Table 1

Effect of different concentrations and combinations of 24-epibrassinolide and

$\mathrm{NaCl}$ on seed germination and growth parameters of squash seedlings

\begin{tabular}{|c|c|c|c|c|c|c|}
\hline \multicolumn{2}{|c|}{ Treatments } & \multirow{2}{*}{$\begin{array}{c}\text { Germination } \\
(\%)\end{array}$} & \multirow{2}{*}{$\begin{array}{l}\text { Shoot length } \\
\qquad(\mathrm{cm})\end{array}$} & \multirow{2}{*}{$\begin{array}{c}\text { Shoot } \\
\text { dry weight (g) }\end{array}$} & \multirow{2}{*}{$\begin{array}{l}\text { Root length } \\
\quad(\mathrm{cm})\end{array}$} & \multirow{2}{*}{$\begin{array}{l}\text { Root } \\
\text { dry weight } \\
(\mathrm{g})\end{array}$} \\
\hline $\begin{array}{l}\text { EBL } \\
(\mu \mathrm{M})\end{array}$ & $\begin{array}{l}\mathrm{NaCl} \\
(\mathrm{mM})\end{array}$ & & & & & \\
\hline 0.0 & 0.0 & $92.4 \pm 4.21^{\mathrm{a}}$ & $12.21 \pm 1.08^{\mathrm{a}}$ & $9.8 \pm 1.56^{\mathrm{a}}$ & $9.7 \pm 1.23^{\mathrm{a}}$ & $8.35 \pm 1.65^{\mathrm{a}}$ \\
\hline 5 & 0.0 & $95.5 \pm 3.88^{b}$ & $13.62 \pm 1.32^{\mathrm{b}}$ & $11.5 \pm 1.06^{b}$ & $11.8 \pm 0.78^{b}$ & $11.03 \pm 1.22^{b}$ \\
\hline 10 & 0.0 & $99.6 \pm 4.23^{c}$ & $17.64 \pm 0.76^{c}$ & $13.9 \pm 1.32^{\mathrm{c}}$ & $13.8 \pm 1.87^{\mathrm{c}}$ & $9.46 \pm 1.07^{c}$ \\
\hline 20 & 0.0 & $93.2 \pm 4.86^{\mathrm{a}}$ & $13.74 \pm 0.76^{b}$ & $11.6 \pm 1.22^{b}$ & $5.3 \pm 1.74^{d}$ & $4.42 \pm 1.03^{\mathrm{d}}$ \\
\hline 0.0 & 50 & $73.6 \pm 4.23^{d}$ & $8.79 \pm 1.32^{\mathrm{d}}$ & $6.8 \pm 1.06^{\mathrm{d}}$ & $5.1 \pm 0.38^{\mathrm{d}}$ & $4.33 \pm 1.21^{\mathrm{d}}$ \\
\hline 0.0 & 100 & $62.7 \pm 2.12^{\mathrm{e}}$ & $5.04 \pm 0.73^{\mathrm{e}}$ & $4.3 \pm 1.43^{\mathrm{e}}$ & $3.1 \pm 1.52^{\mathrm{e}}$ & $3.02 \pm 1.05^{\mathrm{e}}$ \\
\hline 0.0 & 150 & $51.3 \pm 3.12^{\mathrm{f}}$ & $3.32 \pm 0.63^{f}$ & $2.7 \pm 1.32^{\mathrm{f}}$ & $2.4 \pm 1.57^{f}$ & $2.03 \pm 0.11^{\mathrm{f}}$ \\
\hline 10 & 100 & $91.7 \pm 3.62^{\mathrm{a}}$ & $11.88 \pm 1.04^{\mathrm{a}}$ & $9.6 \pm 1.12^{a}$ & $8.9 \pm 1.34 \mathrm{~g}$ & $7.98 \pm 0.22^{g}$ \\
\hline 10 & 150 & $89.2 \pm 4.67 \mathrm{~g}$ & $10.41 \pm 1.43 \mathrm{~g}$ & $8.7 \pm 1.22 \mathrm{~g}$ & $7.2 \pm 1.22^{\mathrm{h}}$ & $7.24 \pm 1.09^{h}$ \\
\hline
\end{tabular}

Data are the means $\pm \mathrm{SD}$ of three replicates. Control $=\mathrm{EBL}$ and $\mathrm{NaCl}$ free media. Means followed by the same letter in column are not significantly different as Duncan's multiple-range test at $\mathrm{P}<0.05$. 
observed at $10 \mu \mathrm{M}$ EBL. EBL treatment of $10 \mu \mathrm{M}$ showed the highest lengths (17.64 and 13.8) of shoot and root, respectively, and the maximum values of shoot and root dry weights (13.9 and 9.46, respectively). So it was chosen as the optimal concentration for the further investigations. Salinity levels $(50,100$ or $150 \mathrm{mM} \mathrm{NaCl})$ significantly decreased the length of shoots and roots as well as their dry weights compared to control. However, the interaction between EBL $(10 \mu \mathrm{M})$ and $\mathrm{NaCl}(100$ or 150 $\mathrm{mM}$ ) expeditiously reduced the deleterious effects of salt stress on growth of seedlings, compared to those of salt treatments alone (Table 1).

Table 2 shows that EBL $(10 \mu \mathrm{M})$ treatment enhanced the contents of chlorophyll a and chlorophyll $\mathrm{b}$ leading to an increase in the total chlorophyll $(\mathrm{Chl} \mathrm{a}+\mathrm{b})$ content compared to control. A similar result was obtained with carotenoid contents; $10 \mu \mathrm{M}$ EBL treatment enhanced the carotenoid contents. However, $\mathrm{NaCl}$ treatments $(50,100$ and $150 \mathrm{mM}$ ) significantly decreased the chlorophyll and carotenoid contents and 150 $\mathrm{mM} \mathrm{NaCl}$ was the most deleterious concentration in terms of chlorophyll and carotenoid inhibition. The $150 \mathrm{mM} \mathrm{NaCl}$ treatment showed the highest decline $(0.41,0.29$, 0.70 and $0.69 \mathrm{mg} / \mathrm{g} \mathrm{FW})$ in chlorophyll a, chlorophyll $\mathrm{b}$, total chlorophyll $(\mathrm{Chl} \mathrm{a}+\mathrm{b})$ and carotenoid contents, respectively. However the interaction between EBL $(10 \mu \mathrm{M})$ and $\mathrm{NaCl}(100$ or $150 \mu \mathrm{M})$ significantly enhanced not only the chlorophyll contents but also the carotenoid contents compared to those of salt treatments alone.

The application of EBL to growing squash seedlings significantly enhanced the accumulation of proline in the seedlings leaves. The accumulation of proline was significantly enhanced in $\mathrm{NaCl}(100$ and $150 \mathrm{mM})$ treated seedlings compared to control (Fig. 1) and $150 \mathrm{mM} \mathrm{NaCl}$ treatment exhibited the highest leaf proline content. The interaction between $\mathrm{EBL}(10 \mu \mathrm{M})$ and $\mathrm{NaCl}(100$ or $150 \mathrm{mM})$ significantly increased the proline contents in the treated plants compared to those of salt treatments alone (Fig. 1).

Table 2

Effect of 24-epibrassinolide $(10 \mu \mathrm{M})$ and different concentrations of $\mathrm{NaCl}$ on the photosynthetic pigment contents in squash seedlings

\begin{tabular}{|c|c|c|c|c|c|}
\hline \multicolumn{2}{|c|}{ Treatment } & \multicolumn{3}{c|}{ Pigment content (mg/g fresh weight) } \\
\hline $\begin{array}{c}\text { EBL } \\
(\mu \mathrm{M})\end{array}$ & $\begin{array}{c}\mathrm{NaCl} \\
(\mathrm{mM})\end{array}$ & Chl-a & Chl-b & Total Chl & Carotenoids \\
\hline 0.0 & 0.0 & $1.29 \pm 0.12^{\mathrm{a}}$ & $0.67 \pm 0.06^{\mathrm{a}}$ & $1.96 \pm 0.02^{\mathrm{a}}$ & $1.64 \pm 0.17^{\mathrm{a}}$ \\
\hline 10 & 0.0 & $1.97 \pm 0.11^{\mathrm{b}}$ & $0.98 \pm 0.03^{\mathrm{b}}$ & $2.95 \pm 0.03^{\mathrm{b}}$ & $2.23 \pm 0.08^{\mathrm{b}}$ \\
\hline 0.0 & 50 & $1.02 \pm 0.14^{\mathrm{c}}$ & $0.61 \pm 0.05^{\mathrm{c}}$ & $1.63 \pm 0.04^{\mathrm{c}}$ & $1.23 \pm 0.54^{\mathrm{c}}$ \\
\hline 0.0 & 100 & $0.53 \pm 0.05^{\mathrm{d}}$ & $0.34 \pm 0.04^{\mathrm{d}}$ & $0.87 \pm 0.01^{\mathrm{d}}$ & $0.86 \pm 0.23^{\mathrm{d}}$ \\
\hline 0.0 & 150 & $0.41 \pm 0.03^{\mathrm{e}}$ & $0.29 \pm 0.04^{\mathrm{e}}$ & $0.70 \pm 0.03^{\mathrm{e}}$ & $0.69 \pm 0.54^{\mathrm{e}}$ \\
\hline 10 & 100 & $1.27 \pm 0.14^{\mathrm{a}}$ & $0.65 \pm 0.02^{\mathrm{a}}$ & $1.92 \pm 0.02^{\mathrm{a}}$ & $1.62 \pm 0.23^{\mathrm{a}}$ \\
\hline 10 & 150 & $1.24 \pm 0.13^{\text {af }}$ & $0.63 \pm 0.05^{\text {af }}$ & $1.87 \pm 0.04^{\mathrm{f}}$ & $1.59 \pm 0.54^{\mathrm{af}}$ \\
\hline
\end{tabular}

Control $=\mathrm{EBL}$ and $\mathrm{NaCl}$ free media. Data are the means $\pm \mathrm{SD}$ of three different measurements. Means followed by different letters in column are significantly different according to Duncan's multiple-range test at $\mathrm{P}<0.05$. 
A similar result was obtained with the reduced sugar content. Data presented in this study showed that the application of EBL $(10 \mu \mathrm{M})$ to the growing squash seedlings significantly increased the accumulation of reduced sugar content compared to control. $\mathrm{NaCl}(100$ and $150 \mathrm{mM})$ treatments caused a significant increase in the reduced sugars content compared with control (Fig. 1) and the maximum value of reduced sugar content was observed at $150 \mathrm{mM} \mathrm{NaCl}$ treatment. The combination between EBL $(10 \mu \mathrm{M})$ and $\mathrm{NaCl}(100$ or $150 \mu \mathrm{M})$ significantly increased the reduced sugar content in the growing seedlings compared with those of salt treatments alone (Fig. 1).

The application of EBL to growing squash seedlings significantly increased the LRWC as compared to control (Fig. 2). However, salinity levels of 100 and $150 \mathrm{mM}$ $\mathrm{NaCl}$ significantly reduced the LRWC value (Fig. 2). The minimum value of LRWC was observed at $150 \mathrm{mM} \mathrm{NaCl}$ and this was reversed with the application of EBL $(10 \mu \mathrm{M})$ to salt stressed plants. The interaction between EBL $(10 \mu \mathrm{M})$ and $\mathrm{NaCl}$ $(100$ or $150 \mu \mathrm{M})$ significantly increased the LRWC of treated seedlings as compared to those of salt treatments alone (Fig. 2).

The electrolytes leakage constitutes an indicator of the membrane permeability and it was measured in squash seedling leaves. EBL application resulted in a significant decrease in the electrolytes leakage percent compared to control (Fig. 2). On the other hand, $\mathrm{NaCl}$ treatments $(100$ and $150 \mathrm{mM})$ significantly increased the electrolytes leakage percent compared to control (Fig. 2) and $150 \mathrm{mM} \mathrm{NaCl}$ treatment induced a highly efficacious effect in terms of high electrolytes leakage percent. However, the

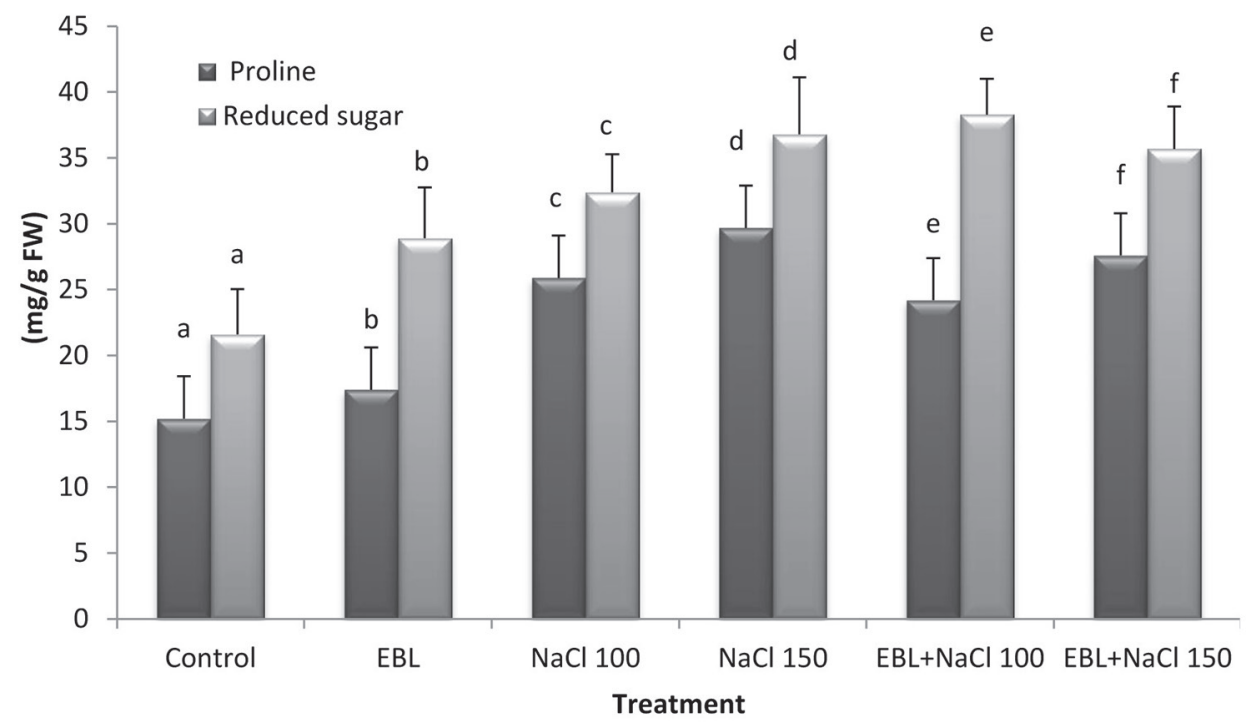

Fig. 1. Effects of 24-epibrassinolide $(10 \mu \mathrm{M})$ on proline and reduced sugar contents in growing squash seedlings under salt stress $(100$ and $150 \mathrm{mM} \mathrm{NaCl})$. Control $=\mathrm{EBL}$ and $\mathrm{NaCl}$ free media. Data are the means \pm SD of three different measurements. Means followed by different letters in column are significantly different according to Duncan's multiple-range test at $\mathrm{P}<0.05$ 


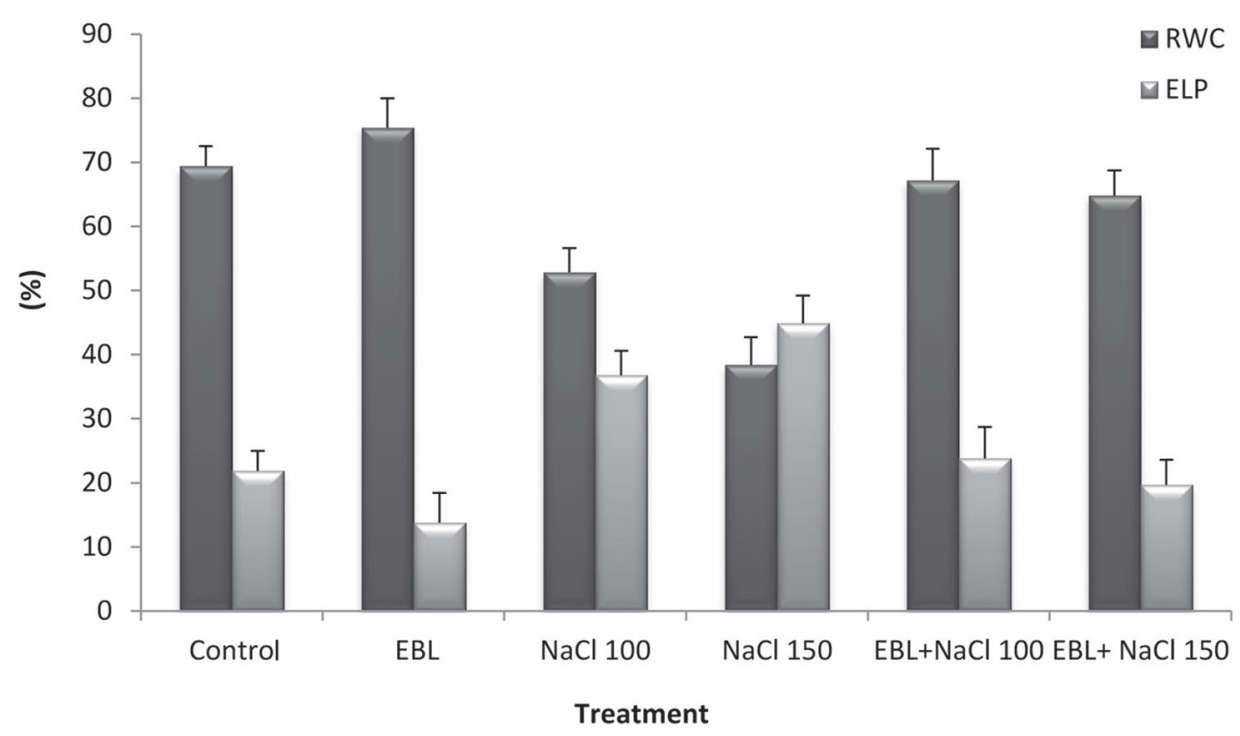

Fig. 2. Effects of 24-epibrassinolide $(10 \mu \mathrm{M})$ on leaf relative water content (LRWC) and electrolyte leakage percent (ELP) in growing squash seedlings under salt stress $(100$ and $150 \mathrm{mM} \mathrm{NaCl})$. Control = EBL and $\mathrm{NaCl}$ free media. Data are the means $\pm \mathrm{SD}$ of three different measurements. Means followed by different letters in column are significantly different according to Duncan's multiple-range test at $\mathrm{P}<0.05$

combination between $\mathrm{EBL}(10 \mu \mathrm{M})$ and $\mathrm{NaCl}(100$ or $150 \mu \mathrm{M})$ significantly reduced the electrolytes leakage percent in treated seedlings, compared to those given salt treatments alone (Fig. 2).

The oxidative damage was observed as malondialdehyde (MDA) content, which is a product of lipid peroxidation (Fig. 3). Lipid peroxidation was evaluated by the determination of MDA concentration in the leaf tissues of growing squash seedling. Salinity levels of 100 and $150 \mathrm{mM} \mathrm{NaCl}$ significantly increased the MDA concentration in the growing seedling leaves, compared to control (Fig. 3), suggesting that the active oxygen species accumulated in salt stressed seedlings. However, the application of EBL $(10 \mu \mathrm{M})$ to growing squash seedling significantly decreased the MDA concentration in the leaves of growing seedlings compared to control. The interaction between EBL $(10 \mu \mathrm{M})$ and $\mathrm{NaCl}(100$ or $150 \mathrm{mM})$ reduced the deleterious effects of the lipid peroxidation in growing seedlings, compared to those given salt treatments alone.

The application of EBL to the growing squash seedlings significantly increased the accumulation of $\mathrm{K}^{+}$and $\mathrm{Ca}^{2+}$, in the leaves of squash seedlings but significantly decreased the accumulation of $\mathrm{Na}^{+}$(Table 3 ). On the other hand, salinity levels of 50, 100 and $150 \mathrm{mM} \mathrm{NaCl}$ significantly reduced the accumulation of $\mathrm{K}^{+}$and $\mathrm{Ca}^{2+}$ but significantly increased the accumulation of $\mathrm{Na}^{+}$. The interaction between EBL (10 $\mu \mathrm{M})$ and $\mathrm{NaCl}(100$ or $150 \mathrm{mM})$ significantly enhanced the accumulation of $\mathrm{K}^{+}$and $\mathrm{Ca}^{2+}$ and decreased the accumulation of $\mathrm{Na}^{+}$(Table 3 ) in the leaves. The salinity treat- 
ment of $150 \mathrm{mM} \mathrm{NaCl}$ exhibited the maximum value of $\mathrm{Na}^{+}$accumulation and the minimum values of both $\mathrm{K}^{+}$and $\mathrm{Ca}^{2+}$ in the leaves of salt-stressed plants. The interaction between $\mathrm{EBL}(10 \mu \mathrm{M})$ and $\mathrm{NaCl}(100$ or $150 \mathrm{mM})$ treatments significantly reduced the loss of $\mathrm{K}^{+}$and $\mathrm{Ca}^{2+}$ in salt-stressed plants (Table 3), leading to a significant decrease in $\mathrm{Na} / \mathrm{Ca}$ and $\mathrm{Na} / \mathrm{K}$ ratios, compared with those having salinity treatments alone.

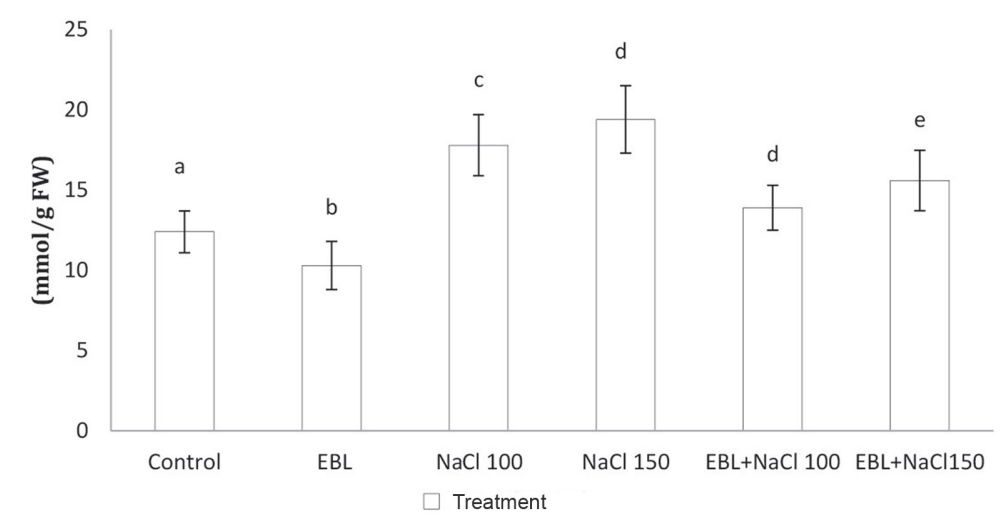

Fig. 3. Effects of 24-epibrassinolide $(10 \mu \mathrm{M})$ on malondialdehyde (MDA) in growing squash seedlings under salt stress $(100$ and $150 \mathrm{mM} \mathrm{NaCl})$. Control $=\mathrm{EBL}$ and $\mathrm{NaCl}$ free media. Data are the means $\pm \mathrm{SD}$ of three different measurements. Means followed by different letters in column are significantly different according to Duncan's multiple-range test at $\mathrm{P}<0.05$

Table 3

Effect of 24-epibrassinolide $(10 \mu \mathrm{M})$ and different concentration of $\mathrm{NaCl}$ on macroelement contents in squash seedlings

\begin{tabular}{|c|c|c|c|c|c|c|}
\hline \multicolumn{2}{|c|}{ Treatment } & \multirow{2}{*}{$\begin{array}{c}\mathrm{Ca}^{2+} \\
(\mathrm{mg} / \mathrm{g} \mathrm{DW})\end{array}$} & \multirow{2}{*}{$\begin{array}{c}\mathrm{K}^{+} \\
(\mathrm{mg} / \mathrm{g} \mathrm{DW})\end{array}$} & \multirow{2}{*}{$\begin{array}{c}\mathrm{Na}^{+} \\
(\mathrm{mg} / \mathrm{g} \mathrm{DW})\end{array}$} & \multirow{2}{*}{$\begin{array}{c}\mathrm{Na}^{+} / \mathrm{K}^{+} \\
(\mathrm{mg} / \mathrm{g} \mathrm{DW})\end{array}$} & \multirow{2}{*}{$\begin{array}{c}\mathrm{Na}^{+} / \mathrm{Ca}^{2+} \\
(\mathrm{mg} / \mathrm{g} \mathrm{DW})\end{array}$} \\
\hline $\begin{array}{l}\text { EBL } \\
(\mu \mathrm{M})\end{array}$ & $\begin{array}{l}\mathrm{NaCl} \\
(\mathrm{mM})\end{array}$ & & & & & \\
\hline 0.0 & 0.0 & $33.0 \pm 2.7^{\mathrm{a}}$ & $32.3 \pm 4.4^{\mathrm{a}}$ & $22.3 \pm 2.49^{a}$ & $0.69 \pm 0.03^{\mathrm{a}}$ & $0.76 \pm 0.01^{\mathrm{a}}$ \\
\hline 10 & 0.0 & $47.4 \pm 2.9^{b}$ & $42.2 \pm 3.8^{b}$ & $17.2 \pm 3.46^{\mathrm{b}}$ & $0.41 \pm 0.02^{b}$ & $0.36 \pm 0.02^{b}$ \\
\hline 0.0 & 50 & $29.2 \pm 2.2^{\mathrm{c}}$ & $27.6 \pm 2.6^{c}$ & $28.4 \pm 3.53^{\mathrm{c}}$ & $1.03 \pm 0.01^{\mathrm{c}}$ & $0.97 \pm 0.04 \mathrm{c}$ \\
\hline 0.0 & 100 & $23.5 \pm 2.7^{d}$ & $21.8 \pm 2.9^{d}$ & $39.5 \pm 4.85^{d}$ & $1.81 \pm 0.02^{\mathrm{d}}$ & $1.68 \pm 0.14^{\mathrm{d}}$ \\
\hline 0.0 & 150 & $16.5 \pm 2.7 \mathrm{e}$ & $19.5 \pm 1.8^{\mathrm{e}}$ & $49.4 \pm 3.86^{\mathrm{e}}$ & $2.54 \pm 0.03^{\mathrm{e}}$ & $2.99 \pm 0.13^{\mathrm{e}}$ \\
\hline 10 & 100 & $36.5 \pm 1.36^{f}$ & $34.7 \pm 4.4^{\mathrm{f}}$ & $19.6 \pm 4.65^{f}$ & $0.56 \pm 0.01^{\mathrm{f}}$ & $0.54 \pm 0.03^{f}$ \\
\hline 10 & 150 & $32.6 \pm 4.1 \mathrm{~g}$ & $38.7 \pm 4.6^{\mathrm{g}}$ & $16.4 \pm 1.88^{\mathrm{g}}$ & $0.42 \pm 0.02^{\mathrm{g}}$ & $0.50 \pm 002^{g}$ \\
\hline
\end{tabular}

Control $=\mathrm{EBL}$ and $\mathrm{NaCl}$ free media. Data are the means $\pm \mathrm{SD}$ of three different measurements. Means followed by different letters in column are significantly different according to Duncan's multiple-range test at $\mathrm{P}<0.05$. 


\section{DISCUSSION}

Squash plants are moderate tolerance to salinity and its vegetative growth was significantly affected by salinity concentration higher than $50 \mathrm{mM}$ [46]. Seed is the only stage in the life cycle of the plant well protected against stresses caused by various factors; soon thereafter when water imbibition and growth process start it becomes sensitive to stress [42]. The findings of this study show that salt stress affected the growth of seedlings and seed germination, but the application of EBL to salt stressed seeds increased the above-mentioned parameters. Plants hormone like BRs have a potential to alleviate the drastic effects of abiotic and biotic stresses [37]. Salt stress significantly impairs the germination percentage [38]. BRs are required for normal growth and development including growth of shoot and root [12] and seed germination $[28,42]$. BRs can reverse the inhibition of seed germination and seedling growth subjected to salinity stress via increasing the contents of proteins and nucleic acids and enhancing the antioxidant system [4]. Ali and Abdel-Fattah [3] pointed out that pre-treating of seeds with BRs enhanced saline stress tolerance during seed germination and growth of seedling through increasing the contents of betaine and glutathione. This result is further supported by Ozdemir et al. [37] who reported that the treatment of salt-sensitive seeds with 24-epibrassinolide improves seedling growth, and alleviates the lipid peroxidation. Studies with BRs biosynthesis mutants and BRs insensitive mutants of Arabidopsis thaliana have also provided evidence that BRs are essential for plant growth and have an anti-stress effect on different plants [12]. For instance, it was shown that BRs help overcome stress exerted by salt stress [37]. The findings of the present study show that 24-epibrassinolide higher concentrations inhibited the root growth of growing squash seedlings. These results are in agreement with those obtained by $\mathrm{Li}$ et al. [28] who suggested that inhibition of root growth under BRs higher concentrations related to inhibition of IAA expression and modulation of polar auxin transport. This view is further supported by Clouse and Sasse [13] who reported that low concentrations of 24-epibrassinolide promote the root formation whereas the higher concentrations inhibit its formation. It has been suggested that BRs could have a positive role on root growth, if its concentration greater than its threshold value and this is genotype dependent [34]. Ten $\mu \mathrm{M}$ EBL was chosen as the optimal concentration to investigate the biochemical aspects of squash under salt stress conditions, because this concentration induced the highly efficacious effect than its other concentrations ( 5 and $20 \mu \mathrm{M})$ in terms of high germination percentage and growth capacity and this concentration was the most effective one that enhanced growth and alleviated the deleterious effects induced by salt stress in a wide variety of plants, such as pea [40] and maize seedlings [2]. Salt stress caused a decline in the contents of chlorophyll and carotenoids in squash seedlings of our study. However, 24-epibrassinolide application to salt stressed seedlings enhanced the values of these parameters. The stimulation of chlorophyll by BRs under salt stress was observed by other researcher [21]. Reduction of leaf chlorophyll content under saline conditions was attributed to an increase in the activity of chlorophyll degrading enzyme, chloro- 
phylase $[4,18]$. BRs reduced the inhibitory effects of salt stress on leaf pigment levels and this could be one of the reasons for growth stimulation by BRs under saline conditions [18]. Clouse and Sasse [13] also reported that epibrassinolide improved the tolerance of plant to salt stress, by reducing the damage via protecting cell ultrastructure and chloroplast membrane system. This suggests that 24-epibrassinolide protect photosynthetic apparatus from salt induced oxidative stress. This view is further supported by the fact that chloroplast is a major source of reactive oxygen species (ROS) [4]. Increased leaf pigment content could be resulted from protection of thylacoidal membranes against the attack of ROS by proline [2, 21]. Yu et al. [47] suggested that BRs affect the biosynthesis of enzymes via an effect on gene expression and/or the effect of BRs on cell membranes. Increase the photosynthesis particularly the capacity of $\mathrm{CO}_{2}$ assimilation in the Calvin cycle, which is mainly attributed to an increase in the initial activity of Rubisco [21].

Salt stress significantly enhanced the accumulation of proline in the growing seedlings of squash. Proline is accumulated in many plants that are exposed to salinity stress $[2,22,27]$ and the accumulation of proline was positively correlated with stress tolerance [2]. Its accumulation is a common metabolic response of higher plants to salinity stress [27]. Houimli et al. [21] showed that among various compatible solutes, proline is the only molecule that has been shown to be able to protect plants against singlet oxygen and free radical induced damage resulting from salinity stress. The application of 24-epibrassinolide to salt stressed squash seedlings significantly enhanced the accumulation of proline in the growing plants. These results are in agreement with those obtained by Ozdemir et al. [37] who reported that the changed pattern of proline after salt and 24-epibrassinolide interaction is related to tissue senescence and saline stress accelerates this process. Proline has been considered as a carbon and nitrogen source for rapid recovery from stress, a stabilizer for membranes and some macromolecules and a free radical scavenger [22]. Sairam et al. [39] noted that proline not only acts as an osmoprotectant, but also as a membrane stabilizer and ROS scavenger, and the increase in proline content could be manifested in terms of improved plant growth. Proline as a cytosolic osmoticum and a scavenger of $\mathrm{OH}$ radical can interact with cellular macromolecules such as DNA, protein and membranes and stabilize the structure and function of such macromolecules [26]. The application of 24-epibrassinolide to salt stressed seedlings of squash significantly enhanced the accumulation of reduced sugar content in the growing seedlings. It is well known that sugars act as osmoprotectant in stress condition. The main functions of sugars are osmotic regulation, carbohydrate storage and also sugars can cause cell membrane and protein stability [46]. BRs play a fundamental role in carbohydrate metabolism by increasing the activity of carbohydrate metabolism enzymes such as sucrose synthase, sucrose phosphate synthase and acid invertase [47]. Reduction of reduced sugar contents in squash seedlings due to salt stress may be attributed to an induced high osmotic pressure which affects hydrocarbon enzyme synthesis.

Salt stress significantly reduced the LRWC in squash seedlings and the application of 24-epibrassinolide to salt stressed seedlings significantly increased it. It has been suggested that LRWC is one of the most important indicators of salt tolerance in crop 
plants $[39,41]$. The decrease in LRWC under salinity stress has already been reported [39]. The decrease in LRWC indicated a loss of turgor, which resulted in limited water availability for the cell elongation process [25]. Increase the relative water content by 24 -epibrassinolide in quash may be attributed to a reduction in water loss. This observation is further supported by Bjornson et al. [12] who reported that 24-epibrassinolide involves in membrane stability leading to protection of plant from stressinduced membrane damage.

Salt stress resulted in a significant increase in the electrolytes leakage percent in squash seedling leaves and the application of 24-epibrassinolide to salt stressed squash seedlings significantly decreased this increase. 24-Epibrassinolide could be protected plant from stress-induced membrane damage and this suggested the stability of cell membrane in squash plants. Increase of the electrolyte leakage is associated with the chain reactions initialized by free radicals [31]. Among these reactions, the lipid peroxidation due to the accumulation of ROS is the principal causes of membrane damage $[6,39]$. It seems that 24-epibrassinolide may help membrane integrity by enhancing the level of the antioxidant system that protects plants from the oxidative damage $[6,12]$. This view is further supported by Asghari and Zahedipour [7] who suggested that this effect is consistent with a protective membrane against the attack of free radicals.

Salt stress resulted in a significant increase in MDA concentration in squash seedling leaves. MDA is regarded as a marker for evaluation of lipid peroxidation or damage to plasmalemma and membranes that increases with environmental stresses [6]. Maintaining integrity of the cellular membranes under salt stress is considered an integral part of the salinity tolerance mechanism [24]. The interaction between EBL and $\mathrm{NaCl}$ induced significant reduction in MDA of squash seedling leaves. The lipid peroxidation due to the accumulation of ROS are the principal cause of membrane damage [6]. It seems that BRs may help membrane integrity by enhancing the level of the antioxidant system that protects the plant from the oxidative damage [40]. Oxidative stress tolerance is enhanced and MDA is decreased [37, 39]. It is widely accepted that active oxygen species (AOS) are responsible for various stress-induced damages to macromolecules and cellular structures [37].

The application of 24-epibrassinolide to salt stressed squash seedlings enhanced the accumulation of $\mathrm{K}^{+}$and $\mathrm{Ca}^{2+}$ in the leaves of the growing plants. In this study, lipid peroxidation and electrolyte leakage also decreased by 24-epibrassinolide application. 24-Epibrassinolide application may increase the tolerance of plants by diminishing ionic imbalance caused by salt stress [14]. Findings of this work are in harmony with the above-mentioned report. $\mathrm{Na}^{+}, \mathrm{K}^{+}$or $\mathrm{Ca}^{2+}$ selectivity is an important factor in salt tolerance. Accumulation of $\mathrm{K}^{+}$and $\mathrm{Ca}^{2+}$ in the leaves of squash seedlings was significantly reduced due salt stress, but $\mathrm{Na}^{+}$increased. Plants may adjust their internal osmotic potential by accumulation of some ions from the surrounding solution [25]. Plants growing in saline soils may suffer dual injury of $\mathrm{Na}^{+}$toxicity and $\mathrm{K}^{+}$ or $\mathrm{Ca}^{2+}$ deficiency $[27,44] . \mathrm{K}^{+}$and $\mathrm{Ca}^{2+}$ are essential macronutrients for all plants; most plants use $\mathrm{K}^{+}$and $\mathrm{Ca}^{2+}$ rather than $\mathrm{Na}^{+}$as an important component of osmotic adjustment [27]. 
$\mathrm{K}^{+}$is considered as one of the primary osmotic components contributing to osmotic adjustment in many plants species [43]. $\mathrm{Ca}^{2+}$ ions increase antioxidant enzyme activities and reduce lipid peroxidation of the cell membrane [25]. It was indicated that $\mathrm{Ca}^{2+}$ increasing had the function of preventing cell membrane injury and leakage, as well as stabilizing the cell membrane structure under adverse environmental conditions [20]. $\mathrm{Ca}^{2+}$ plays a vital role in the maintenance of membrane stability and permeability $[1,17]$. The increase in stress-induced cytosolic $\mathrm{Ca}^{2+}$ has been suggested to up-regulate the biosynthesis, since the induction of transcript for proline biosynthetic enzyme [20]. The decrease in $\mathrm{Na}^{2+}$ content in plants exposed to salt stress may be related to less availability of this element to plant. It appears that $\mathrm{K}^{+}$uptake somehow competes with $\mathrm{Na}^{+}$uptake and $\mathrm{Ca}^{2+}$ mitigates the negative effects of $\mathrm{Na}$ on the plant tissues [1]. Increasing leaf levels of $\mathrm{Na}^{+}$could lead to a $\mathrm{Na} / \mathrm{Ca}$ and $\mathrm{Na} / \mathrm{K}$ imbalance $[1,43]$. The imbalance of $\mathrm{Na}^{+}, \mathrm{Ca}^{2+}$, and $\mathrm{K}^{+}$in plants can lead to some physiological and biochemical disturbances [43]. The control of $\mathrm{Na}^{+}$accumulation and low $\mathrm{Na} / \mathrm{K}$ or $\mathrm{Na} / \mathrm{Ca}$ ratios may enhance salt tolerance $[1,20]$. In this experiment, the results for $\mathrm{K}^{+}, \mathrm{Ca}^{2+}$, and the $\mathrm{Na} / \mathrm{K}$ or $\mathrm{Na} / \mathrm{Ca}$ ratios were similar to those reported by other authors $[43,44]$.

In conclusion: The present study indicated that 24-epibrassinolide application to germinated seeds of summer squash cv. Eskandrani seedlings enhanced a number of morphological and physiological changes in the growing seedlings which leads to excellent plant growth. The response of squash seedlings to 24-epibrassinolide and salinity stress interaction outlined in this study, proved that the steroidal hormone 24-epibrassinolide is able to alleviate the detrimental effects of salt stress in growing squash seedlings and increased the tolerance of seedlings to its deleterious effects.

\section{REFERENCES}

1. Adem, G. D., Roy, S. J., Zhou, M., Bowman, J. P., Shabala, S. (2014) Evaluating contribution of ionic, osmotic and oxidative stress components towards salinity tolerance in barley. BMC Plant Biol. $14,1-13$.

2. Agami, R. A. (2013) Alleviating the adverse effects of $\mathrm{NaCl}$ stress in maize seedlings by pretreating seeds with salicylic acid and 24-epibrassinolide. South African J. Bot. 88, 171-177.

3. Ali, A. A., Abdel-Fattah, R. I. (2006) Osmolytes-antioxidant behaviour in Phaseolus vulgaris and Hordeum vulgare with brassinosteroid under salt stress. J. Agron. 5, 167-174.

4. Anuradha, S., Rao, S. S. R. (2003) Effect of brassinosteroids on salinity stress induced inhibition of seed germination and seedling growth of rice (Oryza sativa L.). Plant Growth Regul. 33, 151-153.

5. Arnon, D. I. (1949) Copper enzymes in isolated chloroplasts. Polyphenoloxidase in Beta vulgaris. Plant Physiol. 24, 1-15.

6. Arora, N., Bhardwaj, R., Sharma, P., Arora, H. K. (2008) 28-Homobrassinolide alleviates oxidative stress in salt treated maize (Zea mays L.) plants. Braz J. Plant Physiol. 20, 153-157.

7. Asghari, M., Zahedipour, P. (2016) 24-Epibrassinolide acts as a growth-promoting and resistancemediating factor in strawberry plants. Plant Growth Regul. 35, 722-729.

8. Azooz, M. M. (2009) Salt stress mitigation by seed priming with salicylic acid in two faba bean genotypes differing in salt tolerant. Int. J. Agric. Biol. 11, 343-350.

9. Bajguz, A. (2000) Effect of brassinosteroids on nucleic acids and protein content in cultured cells of Chlorella vulgaris. Plant Physiol. Biochem. 38, 209-215. 
10. Bates, L. S., Waldren, R. P., Teare, I. D. (1973) Rapid determination of free proline for water stress studies. Plant and Soil 29, 205-207.

11. Behnamnia, M., Kalantari, K. H. M., Rezanejad, F. (2009) Exogenous application of brassinosteroid alleviates drought-induced oxidative stress in Lycopersicon esculentum L. General Appl. Plant Physiol. 35, 22-34.

12. Bjornson, M., Dandekar, A. M., Chory, J., Dehesh, K. (2016) Brassinosteroid's multi-modular interaction with the general stress network customizes stimulus-specific responses in Arabidopsis. Plant Sci. 250, 165-177.

13. Clouse, S. D., Sasse, J. M. (1998) Brassinosteroids: essential regulators of plant growth and development. Annu. Rev. Plant Physiol. Plant. Mol. Biol. 49, 427-451.

14. Çoban, Ö., Baydar, N. G. (2016) Brassinosteroid effects on some physical and biochemical properties and secondary metabolite accumulation in peppermint (Mentha piperita L.) under salt stress. Ind. Crops Prod. 86, 251-258.

15. Dubios, M., Gilles, K. A., Hamilton, J. K., Reberes, P. A., Smith, F. (1956) Colometric method for determination of sugar and related substances. Anal. Chem. 28, 350-356.

16. Fariduddin, Q., Yusuf, M., Hayat, S., Ahmad, A. (2009) Effect of 28-homobrassinolide on antioxidant capacity and photosynthesis in Brassica juncea plants exposed to different levels of copper. Env. Exp. Bot. 66, 418-424.

17. Galal, A. (2017) Physico-chemical changes in karkade (Hibiscus sabdariffa L.) seedlings responding to salt stress. Acta Biol. Hung. 68, 73-87.

18. Hayat, S., Hasan, S., Am, Yusuf, M., Hayat, Q., Ahmad, A. (2010) Effect of 28-homobrassinolide on photosynthesis, fluorescence and antioxidant system in the presence or absence of salinity and temperature in Vigna radiata. Env. Exp. Bot. 69, 105-112.

19. Heath, R. L., Packer, L. (1969) Photoperoxidation in isolated chloroplast. I. Kinetics and stoichiometry of fatty acid peroxidation. Arch. Biochem. Biophys. 125, 189-198.

20. Hepler, P. K., Wayne, R. O. (1985) Calcium and plant development. Annual Rev. Plant Physiol. 36, 391-397.

21. Houimli, S. I. M., Denden, M., Mouhandes, B. D. (2010) Effects of 24-epibrassinolide on growth, chlorophyll, electrolyte leakage and proline by pepper plants under $\mathrm{NaCl}$-stress. EurAsian J. BioSci. 4, 96-104.

22. Jain, M., Mathar, G., Koul, S., Sarin, N. B. (2001) Ameliorative effects of proline on salt stressinduced lipid peroxidation in cell lines of groundnut (Arachis hypogeal L.). Plant Cell Rep. 20 463-468.

23. Jiang, Q. O., Deng, X. Z., Zhan, J. Y., Yan, H. M. (2011) Impacts of economic development on ecosystem risk in the Yellow River Delta. Procedia Env. Sci. 5, 208-218.

24. Kamel, M. (2007) Osmotic adjustment in three succulent species of Zygophyllaceae. Afr. J. Eco. 46 $96-104$.

25. Katerji, N., Van Hoorn, J. W., Hamdy, A., Mastrorilli, M., Mou Karzel, E. (1997) Osmotic adjustment of sugar beets in response to soil salinity and its influence on stomatal conductance, growth and yield. Agric Water Manage 34, 57-69.

26. Kavi Kishor, P. B., Sangam, S., Amruth, R. N., Sri Laxmi, P., Naidu, K. R., Rao, K. R. S. S., Sreenath Rao Reddy, K. J., Theriappan, P., Sreenivasulu, N. (2005) Regulation of proline biosynthesis, degradation, uptake and transport in higher plants: its implications in plant growth and abiotic stress tolerance. Cur. Sci. 88, 424-438.

27. Kaya, C., Tuna, A. L., Ashraf, M., Altunlu, H. (2007) Improved salt tolerance of melon (Cucumis melo L.) by the addition of proline and potassium nitrate. Environ. Exp. Bot. 60, 397-403.

28. Li, L., Xu, J., Xu, Z. H., Xue, H. W. (2005) Brassinosteroids stimulate plant tropisms through modulation of polar auxin transport in Brassica and Arabidopsis. Plant Cell 17, 2738-2753.

29. Lutts, S., Kinet, J. M., Bouharmont, J. (1996) $\mathrm{NaCl}$ induced senescence in leaves of rice (Oryza sativa L.) cultivars differing in salinity resistance. Ann Bot. 78, 389-398. 
30. Ma, H. Y., Song, L. R., Shu, Y. J. (2012) Comparative proteomic analysis of seedling leaves of different salt tolerant soybean genotypes. J. Proteomics 75, 1529-1546.

31. Mazliak, P. (1983) Plant membrane lipids: changes and alterations during aging and senescence. In: Lieberman, M. (ed.), Post-Harvest Physiology and Crop Preservation, Plenum Press, New York, pp. $123-140$

32. Munns, R., James, R. A., Xu, B. (2012) Wheat grain yield on saline soils is improved by an ancestral $\mathrm{Na}^{+}$transporter gene. Nature Biotechnol. 30, 360-364.

33. Murashige, T., Skoog, F. (1962) A revised medium for a rapid growth and bioassays with tobacco tissue cultures. Physiol. Plant. 15, 473-497.

34. Mussig, C., Shine, G. H., Altman, T. (2003) Brassinosteroids promote root growth in Arabidopsis. Plant Physiol. 133, 1261-1271.

35. Nakashita, H., Yasuda, M., Nitta, T., Asami, T., Fujikoa, S., Arai, Y., Sekimata, K., Takatsuto, S. Yamaguchi, I., Yoshida, S. (2003) Brassinosteroids functions in a broad range of disease resistance in tobacco and rice. Plant Journal, 33, 887-898.

36. Ogweno, J. O., Song, X. S., Shi, K., Hu, W. H., Mao, W. H., Zhou, Y. H., Yu, J. Q., Nogues, S. (2008) Brassinosteroids alleviate heat-induced inhibition of photosynthesis by increasing carboxylation efficiency and enhancing antioxidant systems in Lycopersicon esculentum. Plant Growth Regul. 27, 49-57.

37. Ozdemir, F., Bor, M., Demiral, T., Turkan, I. (2004) Effects of 24-epibrassinolide on seed germination, seedling growth, lipid peroxidation, proline content and anti-oxidative system of rice (Oriza sativa $\mathrm{L}$.) under alinity stress. Plant Growth Regul. 42, 203-211.

38. Rajewska, W., Talarek, M., Bajguz, A. (2016) Brassinosteroids and response of plants to heavy metals action. Front Plant Sci. 7, 629-633.

39. Sairam, R. K., Rao, K. V., Srivastava, G. C. (2005) Differential response of wheat genotypes to long term salinity stress in relation to oxidative stress, antioxidant activity and osmolyte concentration. Plant Sci. 163, 1037-1046.

40. Shahid, M. A., Pervez, M. A., Balal, R. M., Mattson, N. S., Rashid, A., Ahmad, R., Ayyub, C. M., Abba, T. (2011) Brassinosteroid (24-epibrassinolide) enhances growth and alleviates the deleterious effects induced by salt stress in pea (Pisum sativum L.). Aust. J. Crop Sci. 5, 500-510.

41. Soares, C., deSousa, A., Pinto, A., Azenha, M., Teixeira, J., Azevedo, R. A. (2016) Effect of 24-epibrassinolide on ROS content, antioxidantsystem, lipid peroxidation and Ni uptake in Solanum nigrum L. under Ni stress. Environ. Exp. Bot. 122, 115-125.

42. Vardhini, B. V., Rao, S. S. R. (2003) Amelioration of osmotic stress by brassinosteroids on seed germination and seedling growth of three varieties of sorghum. Plant Growth Regul. 41, 25-31.

43. Voigt, E. L., Caitano, R. F., Maia, J. M., Ferreira-Silva, S. L., De Macêdo, C. E. C., Silveira, J. A. G. (2009) Involvement of cation channels and $\mathrm{NH}^{4+}$ sensitive $\mathrm{K}^{+}$transporters in $\mathrm{Na}^{+}$uptake by cowpea roots under salinity. Biol. Plant. 53, 764-768.

44. Wang, S. M., Wan, C. G., Wang, Y. R., Chen, H., Zhou, Z. Y., Fu, H., Sosebee, R. E. (2004) The characteristics of $\mathrm{Na}^{+}, \mathrm{K}^{+}$and free proline distribution in several drought-resistant plants of the Alxa Desert. China J. Arid Environ. 56, 525-539.

45. Yamasaki, S., Dillenburg, L. R. (1999) Measurements of leaf relative water content in Araucaria angustifolia. Revista Brasilleira de Fisiologia Vegetal, 11, 69-75.

46. Yildirima, E., Taylorb, A. G., Spittlerb, T. D. (2006) Ameliorative effects of biological treatments on growth of squash plants under salt stress. Scientia Horticul. 111, 1-6.

47. Yu, J. Q., Huang, L. F., Hu, W. H., Zhou, Y. H., Mao, W. H., Ye, S. F., Nogues, S. (2004) A role for brassinosteroids in the regulation of photosynthesis in Cucumis sativus. J. Exp. Bot. 55, 1135-1143.

48. Zhabinskii, V. N., Khripach, N. B., Khripach,V. A. (2015) Steroid plant hormones: effects outside plant kingdom. Steroids 97, 87-97. 